Military Lawyers Making Law: Israel's Governance of the West Bank and Gaza Author: Maayan Geva

The University of Roehampton, Department of Social Sciences, London SW15 5PU, telephone: 0208392 3213, Maayan.geva@ roehampton.ac.uk

Maayan Geva is Lecturer at the University of Roehampton's Department of Social Sciences. The author thanks the following people for comments, criticisms, and editorial assistance: John Lea, Rachel Seoighe and Hedi Viterbo. The author can be reached at Maayan.geva@roehampton.ac.uk. 


\begin{abstract}
This article examines Israeli military lawyers' practice of international humanitarian law (IHL) revolving around the West Bank and Gaza. Based on interviews with legal officers serving in the army between 1967-2009 and archival materials, it interrogates these lawyers' work - the stories that they tell about law, their legal interpretations and their interactions with military decision-makers. This interrogation is set in the context of broader structural, historical and political shifts. Anchored around lawyers' stories about law, their narration of law's relationship with politics and its position in relation to violence, this account sets out to contribute to discussions on lawyers' and by extension law's - past and present positions in states' military affairs.
\end{abstract}




\section{MILITARY LAWYERS MAKING LAW: ISRAEL'S GOVERNANCE OF THE WEST BANK AND GAZA}

\section{INTRODUCTION AND BACKGROUND}

In the past two decades or so international humanitarian law (IHL), the area of law that regulates the conduct of war, has come to the forefront of discussions on Western powers' military conflicts around the world. IHL, which provides a language to make 'sense' of warfare, has come to play a pivotal part in granting a token of legitimacy to state violence. Military lawyers have played a central role in this change, and in recent years they have become invaluable participants in warfare decision-making forums (Dunlap 2001, Lohr and Gallotta 2003, Kennedy 2006, Dunlap 2009).

I use as a case study Israel's military occupation of the West Bank and Gaza, which has been called "the most legalized occupation in world history" (Kretzmer 2002, Ben-Naftali 2011). Israel's reliance on law is entangled in the country's selfperception as 'Jewish and democratic', which, as the political scientist Elian Weizman (2015) argues, represents a clash between a settler-colonial project and purportedly democratic state institutions. In fact, the legal scholar Mazen Masri (2017) posits, while the Israeli constitutional regime is often examined based on the paradigm of a nation-state, it is better explained as part of a settler-colonial project. Nevertheless, Israel's engagement with law has been historically entwined with its contradictory socio-political identity. In a comparative study on US and Israeli engagement with IHL the sociologist Lisa Hajjar observes that:

"The United States and Israel are institutionally invested in self-perceptions as law abiding states, not least because their domestic constituencies expect this. Officials therefore expend considerable effort to rationalize their practices as 
"legal," although international consensus would constitute some as violations of international law" (Hajjar 2006, 22).

Neither country ignores law, Hajjar continues. Instead, they employ law in a manner that she describes as "alternative legality" (Hajjar 2006, 22). Military lawyers play a key part in the making of these alternative legalities.

I investigate lawyers' role in the production-process of legalities. Grounded in fieldwork consisting of interviews and archival materials, I identify three narratives of military lawyering. The lawyers' first narrative is associated with the 1967 occupation of the West Bank and Gaza; the second emerged from the Intifada, which began in 1987; and the third coincided with the Al-Aqsa Intifada, which started in 2000. Some of the key features that differentiate these narratives are the extent of sway that lawyers claim to have, the degree of innovation they identify in their work and the relationship they envisage between law and violence. Alongside these changes, lawyers' stories also moved away from a depiction of law as an entity that is separate from politics and toward a narration of law as being inseparably entwined with politics.

Sociologists researching law have suggested that we think of lawyers as active agents partaking in the making of law, rather than as technicians of a pre-established frame of reference. In this perspective, legal practitioners, rather than passively filling pre-determined roles, play a key part in the process of constituting the contents, possibilities and limitations of law (See Burrage 1989, Abel 1995, Abbott, Keohane et al. 2000, Weisberg 2004, Barzilai 2007, Halliday, Karpik et al. 2007, Cummings 2011, Barzilai 2012). Researchers have shown that legal practitioners constitute 'the legal', set in specific societal, political and historical contexts. They do so in the 
struggles that they choose to take on or not to take on, in the arguments that they choose to make and those that they refrain from making, and in their understandings of law's role in society.

This article contributes to the study of military legal practice and its relationship with violence (Dunlap 2001, Hajjar 2006, Kennedy 2006, Blum 2009, Dunlap 2009, Dickinson 2010, Gregory 2010, Weizman 2010, Weizman 2011, Luban 2013, Jones 2015, Gordon and Perugini 2016, Gunneflo 2016, Hasian 2016, Jones 2016a, Jones 2016b) based on an historical analysis of Israeli military lawyering. Grounded in the analytic perspective of lawyering, I examine military lawyers as active agents in the on-going making of 'the legal' in the context of the West Bank and Gaza. The article interrogates the historical development of lawyers' practice the ways in which they narrate their work, their legal interpretations and their interactions with military decision-makers - from 1967 and until 2009. This article's historical outlook sets out to break with what Craig Jones (2016a) critiques as the tendency of current commentators to assume that a novel relationship has emerged between law and war, thus neglecting the historical continuities in law's involvement with war.

\section{FIELD WORK AND THEORETICAL APPROACH: LAWYERS' PRACTICE} AS A PRODUCTION SITE FOR 'THE LEGAL'

The field materials used in this article originate in a wider research project. This project included 14 interviews with MAG (Military Advocate General) Corps officers between December 2012 and March 2013. These officers included Meir Shamgar, who had served as MAG in 1967 and Amnon Straschnov, who headed the MAG Corps during the first Intifada. Access to MAG officers was not straightforward. After 
a failed attempt at gaining the IDF Spokesperson's Office permission to interview lawyers, I was able to contact MAG officers in informal ways. The interviewing process opened some doors, as several of the officers I talked with introduced me to their colleagues.

This article also draws on archival materials retrieved from the Israel Defence Forces Archive, publicly-available documentation of the military legal system's operations in the West Bank and Gaza and documents given to me by the officers I interviewed. In addition, I examined legal officers' own publications, memoirs, recorded lectures and officers' testimonies to public commissions.

This article is inspired by the body of literature building on 'lawyering' as an analytic prism. This literature conceives of law and legality as the products of political struggle and processes of change and focuses on the ways in which lawyers practice and understand law. By doing so, it excavates lawyers' agency and their active participation in broad legal/political changes. Yves Dezalay and Mikael Madsen (2012) suggest tracing the particular processes of lawyers' group formations as means of studying law and politics. The axis of this perspective is the study of legal practice as an arena constituting legality and its omnipresent counterpart, politics: "[I]t is the jurists who, through their battles within the legal field, constitute a sort of practical metaphor of what becomes the political field." (Dezalay and Madsen 2012, 437-8).

Grounded in a similar theoretical premise, Gad Barzilai (2007) analyses the role that Israeli lawyers play in marking the legal and political spheres. A key element in Barzilai's analysis is silence - lawyers' reluctance to challenge both the Zionist ideology defining the state as Jewish and its agenda on any issues that are said to 
pertain to 'national security.' Similarly, in their ethnographic study of Israeli human rights organisations, Zvika Orr and Daphna Golan (2014) show how these NGOs mark the boundaries of human rights. This marking of boundaries is done by partaking in the Israeli 'collective denial' of the Nakba, which leads to silencing the discussion on Palestinian refugees' right of return. They do so by labelling this right as 'political' rather than 'legal' and by expressly focusing on individual rather than collective rights.

An investigation of lawyering also opens up a space to discuss the ideas, values or assumptions attached to law. As Robert Nelson and David Trubek argue, this perspective can stretch beyond specific actions to include practitioners' imaginaries of law:

"...visions play a role in the structures and in the processes by which structural factors are changed over time, for "structure" is not a set of immanent forces operating independently of human agents. The macro level developments we observe are in some significant respect the product of the ideological dispositions of lawyers and the elements of society with which they interact" $(1992,4)$

My approach to interviews with military lawyers warrants some clarification. I do not relate to lawyers' accounts as a straightforward presentation of 'truth', for several reasons. Firstly, we can safely assume that what interview respondents said was affected by factors such as self-aggrandizing, self-interest, a concern with confidentiality, and a selective recollection of the past. Secondly, my approach builds on Susan Silbey and Patricia Ewick's (1998) methodological and practical understanding of law as the product of social multiplicity. Silbey and Ewick argue: 
"Because the term law names assorted social acts, organizations, and persons, including lay as well as professional actors, and encompasses a broad range of values and objectives, it has neither the uniformity, coherence, nor autonomy that is often assumed." $(1998,34)$

In this perspective, the act of narrating law is part of the process whereby law and legality come into being. Lawyers' accounts, their stories about their work, are neither true nor false, they are instead part of the on-going making of law.

In this sense, Silbey and Ewick continue, interviews set up a stage for stories that "reflect and sustain institutional arrangements, bridging the gap between daily social interaction and large-scale social structures.” (1998, 29). Thus, legal practitioners' stories about law both mirror an existing state of affairs and contribute to its production and reproduction. My analysis places legal stories in the context of military acts and policies, as well as the more general context of political and legal shifts in Palestine/Israel and in international arenas.

Lawyers' stories, as told to me in interviews, contained some dissonances and sometimes contradicted what we know of their work based on external sources. For instance, some of the lawyers who took part in creating the legal foundations of the military occupation of the West Bank and Gaza tell a story of legal work that is untouched by politics. But there is no way of denying that politics played a central part in the construction of this legal regime, for instance with the exclusion of some of the Fourth Geneva Convention from the collection of legal tools applied in the West Bank and Gaza, or with the construction of a complex legal mechanism that enabled Israeli authorities to take over land and build settlements in clear violation of international law. My analysis investigates such tensions and contradictions, and also 
reflects on the instances in which there is more compatibility between lawyers' stories and what is indicated by evidence and external sources. Such contradictions and compatibilities form part of the construction process of law.

This account, which builds on legal practice carried out between 1967 and 2009, also inquires what is distinct about law's involvement with war in recent years. As Craig Jones and Michael Smith rightly point out, "[t]o some degree war has always entailed its rhetorics of justification and regimes of authorization, while the foundations of modern law and order commonly lie, as Weber, Benjamin and Foucault have taught us, in organized (state) violence", but something has changed about justification and authorisation and, "now more than ever, war requires a legal armature to secure its legitimacy and organize its conduct.” $(2015,583)$.

\section{MILITARY LAWYERING IN THE WEST BANK AND GAZA}

The MAG Corps is one of the key legal institutions governing the West Bank and Gaza. Despite the great scholarly interest in the Israeli governance of the West Bank and Gaza, accounts of the MAG Corps are relatively scarce (Craig 2013). It emerged from the 'Haganah', a Jewish paramilitary organisation operating between 1920 and 1948, alongside the British Mandate of Palestine. The Haganah, aiming to operate as an army, tried cases of alleged unlawful conduct in courts, with its members serving as prosecutors and defenders (Inbar 2005). Limited access to information on the MAG Corps has been a key obstacle for researchers (Hajjar 2005, Viterbo 2016). Much of the existing research on the MAG Corps is by retired officers of this system (Shamgar 1971, Shefi 1983, Yahav and Amit-Kohn 1993, Straschnov 1994, Inbar 2002, Finkelstein 2002, Shamgar 2003, Inbar 2005, Sharvit-Baruch and Neuman 2011). These accounts do little to satisfy the need for critical reflection on Israel's 
engagement with law, or on law's role in the military institution.

This article traces three phases of military lawyering that differ in terms of the stories that lawyers tell about law, their legal interpretations and their interactions with military decision-makers. This article is anchored around stories. Lawyers narrate their work in fundamentally different ways in each phase. In the first phase lawyers present themselves as technocrats, in the second phase as an obstacle for violence and in the third as the co-planners of violence. These different stories are entwined with changes in lawyers' legal interpretations and in the ways in which they were involved in military decision-making.

The phases described in this article do not neatly capture the views of all lawyers, and certainly cannot capture the totality of Israel's engagement with law visà-vis the West Bank and Gaza. Reality is always messier and more complex. Notwithstanding, these phases reflect historical changes in terms of law's roles, aims and aspirations. Placed in broader perspective, these phases feed into the complex enterprise that constitutes the legal and the political in Palestine/Israel.

\section{7-1987: A Story of Lawyers as Technocrats}

The MAG Corps' preparation for an occupation scenario preceded 1967. The Israeli army had prepared the Shah'am Plan, a contingency plan for an occupation, as early as 1963 (Inbar 2002, 149-153). These preparations included compiling legal materials and writing up military orders in Arabic and Hebrew, which could be used when Israel took hold of new territories. On June $10^{\text {th }} 1967$, Israel seized the West Bank and Gaza, and the MAG Corps' officers opened up the sealed boxes containing these legal documents (Kretzmer 2002, Shamgar 2013), thereby marking the beginning of a new legal era. Military order number one, which was written in 1963, asserted the 
authority of the Israeli army over the newly occupied territories. This military order, and the many more that followed, played a key part in shaping the Israeli governance of the West Bank and Gaza.

By official accounts, the MAG Corps had a considerable measure of autonomy in the management of the West Bank and Gaza. On July 3rd 1967, several weeks after the act of occupation, Justice Minister Yaakov Shapira made a statement on the Corps' role:

"The Ministry of Justice's work is relatively easy as far as it concerns the areas (...) that were freed by the IDF. The actual governance there is carried out by the military forces and the legal questions that are related to it are handed over to the IDF's legal system, headed by the MAG. The military's legal mechanism handles this task in a manner that can set an example for far more experienced armies, in countries that have traditions of strict adherence to the principles of public international law" (My translation, in Inbar 2002, $150)$.

MAG Meir Shamgar responded to the occupation by ordering the establishment of a division dedicated to international law. Upon its 1968 establishment, the International Law Division (ILD) included only three officers.

Political authorities directed the legal toolkit informing the ILD's practice from the outset. Soon after the military occupation of the West Bank and Gaza commenced, Israeli officials made a critical legal and political decision and declared a selective application of IHL. They asserted the de jure application of the Hague Regulations and despite rejecting the application of the Fourth Geneva Convention, indicated a voluntarily application of the 'humanitarian clauses' of the latter convention (Kretzmer 2002). Notably, Israeli authorities did not disclose which of the 
Geneva Convention's clauses they considered ‘humanitarian’ (Sfard 2004). This selective application of laws was at odds with the orders the MAG Corps had produced in 1963, but new orders were quickly written to adjust to this legal state of affairs (Officer E 2012, Alexandrowicz 2013, Shamgar 2013). The Division's officers built on this 'adjusted' framework to formulate multiple orders to govern the West Bank and Gaza. One of the founding members of the ILD admits in an interview that political actors dictated the army's position on the Geneva Convention: "It was not the hand of God.... Someone came and said that this law might interfere with the future rights of the state of Israel." He conceded that it made little sense to have a policy to only apply the humanitarian articles of the Convention because "the convention is only humanitarian. It deals only with humanitarian problems" (Officer E, 2012).

Another turning point made up of a legal-political arrangement was the 'legalisation' of systematic land grab - an act expressly prohibited by international law - that enabled the Israeli settler-colonial enterprise to expand to the West Bank and Gaza. The legal roots of this project can be traced to a memo addressed to Israeli prime minister Levi Eshkol, written by Theodor Meron, legal adviser to the Ministry of Foreign Affairs, in September 1967. In response to a question by Eshkol on the legality of settlement in the West Bank and Gaza, Meron asserted that while the Fourth Geneva Convention prohibited the establishment of permanent civilian settlements in an occupied territory, a civilian settlement of temporary nature might be established to meet a pressing military need (Erakat 2017). Israeli legal authorities made strategic use of international law. Israel, in Noura Erakat's words, “deployed Occupation Law to incrementally take the land without the people of Palestine" $(2017,20)$. 
The MAG Corps had begun to provide advice based on international law in the early days of the occupation. On June 14, 1967, only four days after the occupation commenced, MAG Meir Shamgar wrote a memo to the Chief of Staff, advising on the army's actions incompatibility with the Geneva Convention. This memo explicitly mentions political considerations, reflecting a clear awareness of the entwined relationship between legal and political concerns:

"In a meeting with the Central Regional Commander, the commander of Brigade 5 commented that he blows up houses in which he finds ammunition. I maintain that this type of reaction is to be avoided: firstly, it is in contrast to the 1949 Geneva Convention, and even regardless of this, the reaction seems to me undesirable in all political and practical senses" (my translation, Shamgar 1967).

Notwithstanding the direct involvement of political authorities and considerations in military legal practice, the lawyers serving in the early days of occupation describe their work as being a straightforward application of a legal code: "The idea was to work by the book... We applied the law as is, without tricks. I didn't try to be smart with the convention" (Officer E 2012). In this story, legal work is the application of a fixed system of rules. Military lawyering is unfettered by political power ("tricks" in this context are political interferences). MAG Shamgar goes further and tells a story of ample confidence in law as a normative force: "My ambition was to educate people to possess knowledge of international law. My dream was then, and I still believe it will come true, at least partially, that we will run an exemplary military regime adhering to all the rules required by international law" (Shamgar 2013). Zvi Hadar (1972), who was MAG in 1973-1978, described his perspective on law's separateness from military and political authority in an article on soldiers' legal 
obligation to disobey their commanders if given illegal orders. The lawyers indicate in these accounts that their vision is to promote the fullest, most complete compliance with law. The maximalist application of law, which includes minimal political disruptions is, in Shamgar's view, a dream in the making. Shamgar's narrative is of particular importance considering his own formative impact on both the military and civil legal systems dealing with the West Bank and Gaza. His declared vision of a legally perfected occupation communicates a sense of strict belief in international law and in law's ability to lay the groundwork for appropriate and supposedly apolitical governance.

Even if the lawyers' story about legal work that is unfettered directly by political authorities were true, this would certainly not indicate an actual divorce of law from politics. The critical legal scholar Martti Koskenniemi (1990) defines international law as a vocabulary for politics. In this perspective, international law and politics form a single identity - the former being an expression of the latter. Antony Anghie's (2006) compelling account of the formation of international law reveals its strong connections with the colonial project. The sovereignty doctrine, Anghie suggests, was part of an exclusionary mechanism that positioned nonEuropean societies outside the realm of power. This exclusion is entwined with the 'dynamic of difference,' which posits a gap and hierarchy between European and nonEuropean cultures. Law then served to justify and legitimise European domination and violence. With these analyses in mind, it is clear that the practice of international law by military authorities, forming part of the Israeli settler colonial project, is anything but apolitical and is inherently entwined with politics and violence.

Another important facet of lawyers' stories, which allows further reflection on law's role and position in relation to political decision-making, is their sense of being 
marginal. To recall, Justice Minister Shapira's had stated that the MAG Corps' lawyers were 'in charge' of the governance of the West Bank and Gaza. The lawyers themselves offer quite a different perspective. In an interview, one of the founding members of the team described their legal work as having very little impact: "We started from zero. The military was not willing to be given advice and to let legal considerations be a part of its decision making processes" (Officer E 2012). This lawyer's perspective is at odds with the legal system's pivotal contribution to Israeli policies applied in the West Bank and Gaza, namely their contribution to the Israeli systematic land-grab. Lawyers' self-depiction as marginal can be partially explained by the structural conditions of their work. While they certainly took part in some important discussions, lawyers were not included in all major state and military decision-making processes. The spatial and temporal separation between operational decision-making hubs and lawyers was not just the result of commanders' reluctance to consider the legal aspects of their plans and actions. At the time legal practitioners themselves did not have a clear idea of how they should be involved in these forums. Dov Shefi, the first ILD's Commanding Officer, made this point in an article: “The exact nature of the cooperation between the legal adviser and the combatant forces is still not clear. (...) the legal adviser can assist in solving problems arising in the field even from his or her position in the rear" $(1983,130)$. While the MAG Corps was a key legal institution overseeing the army's conduct in the West Bank and Gaza, it did not exercise much supervision on many of the army's actions and operations. The MAG Corps' officers narrate a grand perception of their role and the position of international law but the Division's structural positioning meant that it would have been difficult for its officers to impact decisions made by operational ranks and political authorities. 
Thus, the stories that military lawyers tell about their work are not fully in line with what we otherwise know about their legal practice. They were legal technicians, they argue, whose work was separate from politics, and their practice had a relatively marginal impact in the military establishment. This story prevailed despite the obvious influence of political agenda and involvement of political authorities in legal policies, and despite the creativity required to reach legal interpretations that contradict international law. Notwithstanding the pivotal part that law played in the Israeli handling of the West Bank and Gaza, military lawyers were positioned spatially and temporally away from regular operational decision-making forums. Their institutional position was translated into a sense of being marginal, or separate from, many of the army's decision-making processes. There was an implicit assumption in practitioners' stories about law: that while politics may interfere with legal decision-making at times, these interruptions somehow do not challenge the purity of law and its fundamental separateness from politics.

\section{7-2000: A Story about Lawyers as an Obstacle For Military Violence}

The 1987 popular uprising, the Intifada, marked a new era in the military occupation of the West Bank and Gaza, when largely unarmed mass demonstrations were met with harsh military measures. State-military apparatuses, in collaboration with the MAG Corps and its ILD, developed various policies aimed at supressing the Intifada. These policies included wide-scale administrative detentions, house demolitions, curfews, closure of Palestinian institutions such as schools and universities, and a reformulation of the army's rules of engagement.

The Intifada unfolded alongside a legal transformation in Israel, namely the High Court of Justice's (HCJ) attainment of power and the emergence of 
an Israeli human rights movement. The 1980s was an era of relative political instability in Israel, when the two major parties, Ha'Avoda and Ha'Likud, had not gained sufficient electoral support to allow either of them to form a stable coalition. In the absence of political stability, the sociologist Gad Barzilai (1997) argues, the HCJ filled up the space of authority. The court gained unparalleled prominence and was seen as the country's most reliable civil institution. With its newly gained power, the court took it upon itself to review almost all controversial affairs in the country.

The Intifada was a decisive factor in the emergence of the Israeli human rights movement. The sociologists Neve Gordon and Nitza Berkovich (2007) observe that Israeli human rights organisations emerged as a result of the parallel global rise of human rights and the Palestinian resistance. In this sense, they pointedly argue, Palestinians brought human rights to Israel. The establishment of these NGOs affected the MAG Corps, because the legal institutions concerned with the military occupation of the West Bank and Gaza - the military legal system, the HCJ and NGOs - operated in conjunction with one another. In the years to follow, the HCJ was flooded with hundreds of petitions, many of which were submitted by recentlyestablished human rights NGOs (Kretzmer 2002).

In 1989 the ILD included only five lawyers (Craig 2009), an indication of the normative and institutional authority afforded to legal officers at this time. Amnon Straschnov (2013), MAG in 1986-1991, said in an interview: "Decision makers didn’t tend to consult with us unless they absolutely had to." This situation would change. According to senior military lawyers, the Intifada was the most legalistic military affair that the Israeli army had carried out to that point (Yahav and Amit-Kohn 1993, Straschnov 1994). 
The MAG Corps' practitioners decided that the existing international laws did not provide them with adequate tools to handle the new situations in the West Bank and Gaza as a result of the Intifada. This perspective facilitated new policies supported by creative interpretation of laws. In stark contrast to their predecessors' self-depiction as legal technocrats, they described legal practice during the Intifada as a radically innovative operation. The ILD's Commanding Officer, David Yahav, says in an interview:

"There were no precedents to the things that we did with international law. We couldn't open a book and see what's the solution... Everything was very new. International law addresses peace and addresses war. It doesn't address a situation of a popular uprising that is partly violent and partly not so violent (...) there were no legal sources for that, and we had to create them" (Yahav 2013).

MAG Straschnov depicted legal practice similarly in his memoir:

"While the law of peace and war was made mainly in Geneva and the Hague based on the lessons of the battlefields of Europe, the laws of popular uprising were created and institutionalised in Tel Aviv and Jerusalem, based on the riots and disturbance of public order in Nablus, Gaza and Jenin” (My translation, 1994, 10).

The comparison between the writing of laws in Geneva and The Hague on the one hand and by the Israeli military legal system on the other hand, encapsulates the extent of the MAG Corps' innovative spirit. Whatever changes the Israeli military system had undergone from the late 1980s to the present day, innovation has been a persistent facet of military lawyers' narratives of their work. 
An example of lawyers' creative legal interpretations was the treatment of children who threw stones at soldiers. Prior to the Intifada, the age of legal liability enforced by Israeli authorities in the West Bank and Gaza was 12 (Straschnov 1994). In May 1988 the MAG Corps devised a military order that enforced legal liability for younger children in certain circumstances. The order required that parents of children younger than 12 who had been accused of throwing stones place a monetary deposit with the military authorities. The deposit was to be reinstated to the family in one year's time, provided that the child concerned had not been charged with a similar offence in the duration of that year. NGOs challenged this policy in the HCJ, which ruled it legal (HCJ 591/1988). MAG Straschnov (1994) described the inclusion of children as potential defendants under the Israeli legal system as an innovative violence-lessening solution for a problem on the ground, because soldiers were less likely to resort to violence if they were equipped with a legal tool to deal with such situations. Perhaps this measure could be more accurately described as the substitution of one type of violence with another. By including children in the military's legal regime and making them potentially subject to the army's punitive system, military lawyers expanded law's jurisdiction and the violence that accompanies it.

When the military decided to expand the weaponry it utilised in its dealing with the uprising to include rubber-coated metal pellets, it consulted with the MAG Corps about when and how it will use these pellets. The very participation of lawyers in these discussions marked a change, because prior to this occasion lawyers were largely not included in discussions on weapons and the terms of their usage. The army's Chief of Staff stated that rubber-coated metal pellets are not lethal when fired from a distance exceeding 70 meters and that orders prohibit firing them from a closer 
range (Ginosar 1988). MAG Straschnov (1994) described the imperative behind lawyers' involvement in these discussions as an effort to curtail military violence. While it is plausible that if it hadn't been for their involvement in these discussions military decision-makers were to reach more permissive rules of engagement, lawyers' participation in these discussions contributed to the legitimacy of their outcome. Contrary to the Chief of Staff's statement, this measure proved lethal. The army started making use of these bullets in August 1988 (Talmor 1990), and by January 1989 the IDF Spokesperson admitted that 47 Palestinians had been killed as a result of rubber-bullet shooting. By March 1990 the number rose to 128 (IDF 1990). The lawyers' participation in these discussions contributed to that Israeli authorities came to see the shooting of Palestinians with rubber-coated metal pellets as legal and legitimate.

Around the beginning of the Intifada, Defense Minister Yizhak Rabin was famously quoted as instructing military commanders to 'break arms and legs' as a means of repressing the uprising (New York Times 1990). This instruction led to a clash between political authorities and the legal officers. ILD Commanding Officer David Yahav describes this situation: "There was that phase of 'Break their arms and legs' and I told him [MAG Straschnov] that if there was no direct guidance from the Chief of Staff [to stop the beatings], then I will quit...I felt that the situation was very fragile" (my translation, Yahav 2013). MAG Straschnov (1994) recounted circulating a memo demanding that commanders put an end to these beatings. The memo, he writes, resulted in confrontations with both military and political officials. In their approach to beatings of Palestinians by Israeli soldiers, lawyers offered legal interpretations and told stories that positioned law in opposition to politics. 
The lawyers were involved in decision-making processes more than ever before during the Intifada, and much of this involvement was confrontational. Straschnov (1994) placed these confrontations at the center of his memoir focused on his experiences as MAG during the Intifada, which he tellingly entitled Justice Under Fire. Ilan Shiff, the MAG to follow Straschnov, dryly describes this situation in an interview: "The MAG Corps has always seen itself as the watchdog of the rule of law, and this led to uneasy arguments" (Shiff 2013). These narratives depict law as a force limiting and restraining the violence of military and political policies. In an interview, ILD Commanding Officer David Yahav says in this context: "Our job was to protect human rights... there are universal norms and values. We had a key role to play in that" (Yahav 2013). MAG Straschnov shares this same perspective: "If there was a restraining factor guarding human rights in the Intifada it was the MAG Corps" (Straschnov 2013). There are obvious tensions between these stories about law as a force in the way of violence and politics and the actual impact of the lawyers' legal interpretations. Nonetheless, these imaginaries of law yielded legal practice that, at times, prevented some types of violence.

The MAG Corps' work is inseparable from the HCJ's increase of power, which was affected, in turn, by the rise of human rights. The MAG Corps' authority in military decision-making processes was supported by the potential or actual review of the army's policies in court, because state and army officials knew that they would benefit from legal arguments supporting their actions if these actions were to be later reviewed in court. As David Kretzmer (2002) observes, this support curiously persisted even though the court by and large refrained from reaching judgements that went against state/military policies affecting the West Bank and Gaza. The military legal system's decisions provided material that the court discussed in its deliberations, 
which ended, in the vast majority of cases, with the judges supporting the MAG's position over Palestinians' human rights.

Lawyers' work in the Intifada - the stories that they tell about law, their legal interpretations and the nature of their interactions with military decision-makers - is significantly different from that of their predecessors. The lawyers' work revolving around the legal liability of children, rubber-coated metal pellets and beatings of Palestinians by Israeli soldiers reflected their increased involvement in operational military affairs and their efforts to offer innovative solutions to the military's challenges. The hands-on nature of their legal work marks a change between them and their predecessors, as does their narration of legal work as an innovative endeavour, which is quite the opposite of their predecessors' supposed technocracy.

A key element in the lawyers' stories was that they forced their way into the room in order to impose legal considerations on military decision-making. The lawyers' stories about their work position them as defenders of Palestinians' human rights, as obstacles in the way of violence. The reality is more complex. As their contribution to the adoption of rubber-coated metal pellets as well as their initiative to make young children legally liable for their actions show, the lawyers were not standing in the way of all violent measures insomuch as they were standing in the way of certain types of violence. Nonetheless, lawyers embraced a vision of the law as a force to restrict political desires and lessen the violence directed at individuals. They narrated their role as antagonistic to the military establishment and to political authorities. Even though there is a clear gap between this imagination of their work and reality, as the work of their successors will clarify, the very idea of a separation between law and politics facilitated a particular type of legal work. 


\section{0 - Present: A Story of Lawyers as the Co-Planners of Military Violence}

The Al-Aqsa Intifada, which began in September 2000, was triggered by the visit of opposition leader Ariel Sharon to the compound of the Al-Aqsa Mosque in Jerusalem. The root causes for the uprising were Palestinian disillusionment with futile peace processes and negotiations as well as a host of abusive Israeli policies. The uprising started with violent demonstrations in the old city of Jerusalem and soon spread throughout the West Bank and Gaza. These demonstrations were met with a brutal response by the Israeli armed forces. Over the following years, the Intifada continued with strikes, demonstrations and attacks on Israeli armed forces and civilians, including lethal bombings in Israeli cities. The Palestinian death toll in clashes with Israeli armed forces from September 2000 and until Operation Cast Lead in 2008 was 4,860. The Israeli death toll for this period was 332 armed forces personnel and 731 civilians (B’tselem 2016).

The turning point in the governance of West Bank and Gaza was a radical change of approach in the Israeli practice of IHL. Although IHL has provided the legal toolkit governing the military occupation of the West Bank and Gaza since its inception, until 2000 the army based its conduct on a logic of policing rather than a more militarised form of governance. With the Al-Aqsa Intifada, both military policy and the rhetoric that accompanied it shifted toward increased militarisation and securitisation (Hasian 2016).

The MAG Corps and its ILD, which had been elevated from a division to a department in the 1990s, began labelling military dealings in the West Bank and Gaza as an 'Armed Conflict Short of War.' This model is not exactly about a state of war, but is quite removed from a state of policing. It facilitated an array of policies that were supported by what Lisa Hajjar (2006) called 'alternative legalities,' meaning 
legal interpretations that depart from international consensus.

For the MAG Corps, the shift to the Armed Conflict Short of War model had multiple implications. This meant, first and foremost, a significant expansion of the spectrum of legally acceptable actions. As a result, lawyers, in collaboration with military decision-makers, designed new policy permitting measures such as targeted killings, deportations and house demolitions. This deeper integration of IHL into the Israeli army's operations allowed lawyers entry into areas of military decision making from which they had previously been excluded. The ILD grew in personnel from 1968 to 2009 at a rate that rendered it the army's fastest growing body (Cohen 2011, 376) and by 2009 it included twenty lawyers, who were joined by reserve officers in times of military operations (Craig 2013, 143).

The Israeli adoption of the Armed Conflict Short of War paradigm was directly affected by the US 'war on terror.' Prior to the September $11^{\text {th }}$ attacks, US officials had encouraged Israeli military lawyers to return to the framework of policing in dealing with Palestinians in Gaza and the West Bank (Mitchell 2001). Only after 9/11 did American officials accept the new Israeli approach. A Senior ILD figure had said to this effect: "It took four months and four planes to change the opinion of the United States, and had it not been for those four planes I am not sure we would have been able to develop the thesis of the war against terrorism on the present scale" (Reisner in Feldman and Blau 2009).

The 2008-2009 offensive, named 'Operation Cast Lead' by the Israeli authorities, was the most destructive attack on Gaza since 1967. The army's legal system was more extensively involved in this attack than in any past military operation. Examining the coincidence of the intensification of legal consultancy and the extreme violence employed in Gaza, Eyal Weizman $(2010,2011)$ asks if these are 
cause and effect - if law, as practiced in Gaza, had intensified military violence. Two of the legal policies that shaped the Israeli violence in Gaza were the MAG Corps' interpretations of the distinction between civilians and combatants and the measure of early warning. Both these policies and the legal stories that accompany them demonstrate the ways in which lawyers' understandings of their role changed and how their deepened integration into operational forums impacted the military's conduct.

The wartime distinction between civilians and combatants is one of the pillars of IHL. It classifies people and objects into categories, the former entitled to protection from hostilities and the latter being legally permissible targets of attack. The ILD's interpretation of the civilian/combatant distinction in Gaza decisively expanded the 'combatant' category and directed violence accordingly. The treatment of Gaza's police force is an illuminating example of this legal expansion. The ILD's lawyers had decided to classify the Gazan police as a combatant entity in the planning process of Operation Cast Lead. A senior legal officer described this decision: "This is a very large group of people who were supposedly, at that moment, civilians, and the following day turned into legitimate military targets" (in Blau and Feldman 2009). The classification of police personnel and stations as legitimate targets of attack, a deconstruction of the previously existing boundary, had detrimental implications. On its first day, the Israeli offensive included massive artillery, which hit a hundred targets. Out of the sites targeted, twenty-four were police stations. By the time the operation's artillery attacks had ended, all sixty Gazan police stations had been struck (Fogelman, 2010). The inclusion of Gazan police forces in the legal category of 'combatant' directed the attacks on the ground and it is therefore crucial to closely examine this decision and the conditions that facilitated it. 
Questions about, or challenges to, the identification of combatants and civilians are certainly no novelty and can be found in both ancient and modern contexts (Slim 2003). These issues have become particularly prominent on the international agenda in the 2000 s, a legal era shaped by the 'war on terror,' leading the ICRC (2008) to publish guidelines addressing 'direct participation' in combat, meaning the times and situations in which people who are not 'formal' participants in hostilities lose the protection afforded to civilians. The ILD's legal interpretations pushed all these questions to their extremities.

The inclusion of Gazan police forces in the combatant category relied on a hypothetical scenario: if attacked and presented with an opportunity to fight back, these forces would potentially do so (Feldman and Blau 2009). In this sense, the Israeli strike itself is the factor determining the wartime classification of the people involved, rather than their intrinsic characterization or their actions. This decision's reliance on a hypothetical scenario was not exceptional in terms of its rationale, and it is largely in line with the general logic of IHL. That same year, ILD Commanding Officer Pnina Sharvit-Baruch presented a similar argument at a conference: "what is a military target? (...) this is very flexible. A civilian object, when it is used [for military purpose], or because of its location, or even because of its potential use (...) becomes a legitimate target of attack" (my translation, Sharvit Baruch 2009). Following this logic, a hypothetical chain of events provides sufficient grounds for the making of a combatant. Crucially, it is unclear what the limits are for these hypothetical scenarios. Notably, the action or potential action of the aggressor can, in and of itself, determine a person/object's status as being a legally permissible target of attack, because identifying a 'civilian object' as having 'potential military use' depends exclusively on the attacking power's actions and plans. 
The logic underlying police officers' identification as combatants is also similar to the rationale that Neve Gordon and Nicola Perugini (2016) identify in the Israeli rhetoric applied to Gazan facilities. Grounded in Derek Gregory's notion of 'moral cartography', Gordon and Perugini detect a semiotic transformation of space and a blurring of legal definitions that assign combatant qualities to Gazan facilities, for example in the attribution of a double function to homes, which at once serve as a shelter for civilians and as a storage space for ammunition. The latter function overrides the former to justify the killing of civilians. The Gazan police force was also assigned a double function. While it is dedicated to civilian tasks in its regular work, it was assumed to possess a second, hidden function that might reveal itself when faced with an Israeli attack.

Early warning procedures are another policy that exemplifies the contemporary character of military legal practice. The ILD's lawyers instructed the employment of unprecedentedly extensive methods of early warnings in Gaza. These measures included text messages, leaflets, phone calls and missiles that were meant to 'knock' on roofs and alert people of a coming attack (Sharvit-Baruch and Neuman 2011). Early warnings provided people with either an actual or hypothetical chance to escape, and then marked all those who had stayed as legitimate targets of attack. After a warning had been issued, those who had not fled were assumed to be either directly involved in hostilities or to be acting as "human shields" for adversaries. Either option rendered these people a legitimate military target (Weizman 2010). Thus, the communication of an early warning, with the launching of missiles being its most extreme manifestation, is at once an operational and legal action. This practice exemplifies the act that Derek Gregory $(2010,177)$ names 'excepting', which is “the use of politico-juridical instruments to exempt categories of people from the 
responsibilities or the protections of the law. Within these spaces law and violence feed one another."

Much of the discussions on law's contemporary relationship with war are anchored around the term 'lawfare'. The term has often been associated with former Military Advocate of the US Air Force, Charles Dunlap, who used it to depict legal argumentation and action as a form of weapon employed by the weaker side of a conflict fighting against a Western power, in a "cynical manipulation of the rule of law and the humanitarian values it represents" (Dunlap 2001, 4). Jones (2016b) uses this term in an entirely different way - to describe an expansive legal framework that deconstructs the normative and legal boundaries of war. Any restrictions are removed and the whole world becomes a legally permitted battlefield.

Customary law, a set of laws predicated on state practice and opinion, provides particularly fertile grounds for wartime law-making, or legal war-making. Under the circumstances where law has expanded beyond previous limitations, Israel and the US engage in law-making through the violation of law, to form new custom. In Eyal Weizman's words:

"Military attacks may thus do two simultaneous and seemingly paradoxical things: violate the law and retroactively shift it to exonerate the act. In this cyclical logic, the illegal becomes legal though continuous violation and retroactive rewriting. This is a law in action, legislative violence as seen from the perspective of those who seek to violate it" $(2010,25)$.

I would like to consider two particular elements in Weizman and Jones' analyses that are reflected in the policies executed in Gaza based on lawyers' stories the re-writing international law and law's relationship with violence. I also suggest 
that much of what is new about legal practice is directly connected to the current position of law and legal work in military decision making-processes.

As discussed, building on the legal reform that adopted the Armed Conflict Short of War paradigm, lawyers offer legal interpretations that re-write law and defy international consensus. As one lawyer describes:

"We defended policy that is on the edge: the "neighbor procedure" [making a neighbor knock on the door of a potentially dangerous house], house demolitions, deportation, targeted assassination (...) The army says, "Here is a magic formula, is it within the bounds of what is possible?" To which I will reply, I am ready to try to defend it, but I am not sure I will succeed. If it's white I will allow it, if it's black I will prohibit it, but in cases of grey I will be part of the dilemma: I do not stop at grey." (Reisner in Blau and Feldman 2009).

The military lawyers' innovative approach fits into a broader Israeli narrative whereby state institutions are reinventing international law. Asa Kasher, the author of the 'IDF Code of Ethics' and the man dubbed 'the IDF's philosopher' has argued to this effect:

"We in Israel are in a key position in the development of law in this field because we are on the front lines in the fight against terrorism (...) My hope is that our doctrine, give or take some amendments, will in this fashion be incorporated into customary international law in order to regulate warfare and limit its calamities" (Kasher 2010).

Eyal Weizman (2011) argues that the ILD's lawyers, while participating in planning the attacks on Gaza, produced 'elastic law,' meaning that their legal work pulled, bent, and expanded law. However, Israeli military lawyers have been working 
with law in such a manner since the inception of the military occupation of the West Bank and Gaza. Moreover, military lawyers' own narrative by which they are rewriting law is also not new. I have shown that lawyers have been narrating their work in terms of radical legal innovation and offering interpretations that openly move away from the existing laws since the late 1980s.

What is different is lawyers' stories about their role, and about the role of law, vis-à-vis military violence. In stark contrast to their predecessors, military lawyers no longer tell stories of law as a force defending individuals by taming military violence. Some of the officers I interviewed were surprisingly blunt in this regard. When asked explicitly if legal practice reduced civilian fatalities, a senior MAG Corps officer replied: "Do we prevent harm to civilians?... I don't know... maybe... I'm not sure... I'm not sure it [law] lessens harm... The opposite is sometimes true..." (Officer D 2013).

When the lawyers describe their work advising military leaders in this period, they tell stories in which law, rather than taming violence, enables it. An officer serving in the ILD at this time described this relationship in a media interview: "Our purpose is not to place restrictions on the army, but to provide it with the tools for victory, in a way that is legal" (in Blau and Feldman 2009). Similarly, Avichai Mendelblit, MAG in 2004-2011, stated: "We need to help the military win at the end of the day, and we can't forget that... But winning legally, and it is possible, if you don't tie things down too much..." (Mendelblit 2010, 65). Another officer describes a situation where he 'authorised' an attack that the military commanders had assumed was not permitted by law: "They [the commanders] thought it is not allowed to attack mosques, but I, the legal practitioner, tell them that it is allowed. You can attack, no problem" (in Geva 2016, 175). Lawyers now tell a story in which they actively 
construct violence, direct it and widen its scope. Law, as they understand it and as they practice it, has become agnostic to its implications.

These lawyers' stories are in fact closely aligned with critical analyses of law's position vis-à-vis state violence. Lawyers' conceptualization of law is an explicit demonstration of Walter Benjamin's insight into law and the state by which military violence has an inherent law-making character to it (Gunneflo 2016).

As the Al-Aqsa Intifada brought an increasing role for lawyers in military operations, government officials became concerned about lawyers exercising an excessive extent of power in military decision-making processes and an anxiety about 'confusion' as to the source of battle-time responsibility and authority. The government-appointed Winograd Commission $(2008,488)$ concluded that military lawyers should provide advice prior to operations and then review the results of attacks, but should not be involved in operations as they unfolded. My analysis, which traces a deepened involvement of lawyers in military operational decision-making, implies that these recommendations were not implemented.

Anxiety about wartime authority in the legal-political matrix is a timely topic for Western armies. David Kennedy pointedly articulates this state of affairs, where wartime decisions are outsourced to legal arenas:

"We no longer need to decide for ourselves whether war is civilized, whether killing this civilian is a good idea, whether attacking the town is ethically defensible. The law of armed conflict will do that for us - while lending itself to strategic deployment" $(2006,141)$.

The entwined relationship between law and war is, of course, no novelty. What is new is the translation of this relationship into a close bind where lawyers are an inseparable part of war-making forums. The Israeli case demonstrates that the 
contemporary form of this relationship both changes the way decisions are made to include lawyers and legal considerations in an unprecedented manner and also, in the process, shapes lawyers' interpretations of law. An ILD officer describes this integration: "The only reason why they [military lawyers] can sit beside commanding officers and be listened to, and have their say taken into account, is that they are a part of the system" (in Geva 2016, 172). This proximity signals the emergence of a circular dynamic. Lawyers are able to influence military action precisely because they are part of 'the system' and they do not attempt to 'tie things down too much'. In previous eras, military lawyers did not fully identify themselves in this manner. In the early years of the occupation, lawyers were removed from decision-making hubs and in the late 1980s, when coming closer to military decision making forums, lawyers described their work as standing in the way of operational and political interests. In the present era, practitioners no longer narrate law as being at all separate from operational and political logic.

\section{CONCLUSION}

Investigating the Israeli military legal system grounded in practitioners' accounts and secondary sources, this article identified significant changes in lawyers' work - the stories that they tell about their role as army lawyers, the legal interpretations that they offer and the type of interactions they have with decision-makers. In the early years of the military occupation of the West Bank and Gaza, while working in and around law in highly 'creative' ways, lawyers characterized their work as a technical operation. Notwithstanding apparent dissonances, they talked of law that is, at its core, removed from politics. 
Lawyers' work changed considerably alongside the 1987 Intifada. Lawyers then openly depicted their work as an innovative operation, which they equated with the re-writing of law. Lawyers fought to get into military decision-making forums and then advised on multiple policies. While these policies legitimized some new forms of violence, lawyers described their work as an on-going endeavor to limit state/military violence. This story narrated law as different from, and at times contradictory to, political violence. Military lawyers' work changed again in 2000, alongside the Al-Aqsa Intifada. Armed with an increased innovative spirit, lawyers became vital participants in military decision-making forums and, by offering legal interpretations that moved away from international consensus, played a key part in designing warfare. Law, in these practitioners' stories, no longer sets out to restrict violence nor does it clash with political agenda.

The reasons behind the changes in lawyers' practice are multifold and interrelated - a key factor is the changing position of lawyers and law vis-à-vis operational decision-making. As I have shown, lawyers were positioned in 'the rear' in the 1960s and 1970s, forced their way into the room in the late 1980s and then became regular participants in military decision-making forums from the 2000s onwards. This certainly does not indicate that lawyers were unimportant in the early days of the Israeli military occupation. Indeed, some of the most important politicallegal decisions concerning the West Bank and Gaza were made at this time. Nonetheless, lawyers were not systematically integrated into decision-making processes. This is not a technical insistence - there is a difference between inviting the lawyer to a meeting in order to 'legalize' a political decision and having lawyers present all the time, partaking in any and all key operational decision-making. 
Lawyers' changed involvement in military affairs and their changed stories are also directly related to legal/political shifts in Israeli society and polity, which are in turn affected by changes in international arenas. The emergence of a human rights community as a response to the Intifada, unfolding alongside the HCJ's gain of power led to a situation whereby many of the army's actions were discussed in court. This meant that lawyers had to be more involved in military affairs so that army and state representatives were able to counter the NGOs' arguments effectively. The trend by which governments are increasingly expected to respond to human rights claims is by no means unique to Israel. This shift, in Israel and elsewhere, led to some unintended implications - rather than reducing the use of force, as human rights advocates had hoped, it has structurally encouraged the integration of law into state/military mechanisms in a manner that in some cases further erodes human rights.

The 'war on terror' re-arranged the set of circumstances against which law was practiced in the Israeli army. The political/legal permissiveness it created allowed the MAG Corps to significantly alter the toolkit informing its legal work. This leniency, which facilitated a deepened integration of lawyers in military affairs, was entwined with legal interpretations that set out to please operational-political desires more than ever before. This was the basis for the discursive legal/political merger of logic and intents that facilitated the brutal violence seen in Gaza in recent years. This process is not an Israeli particularity. As Western armies bring legal practitioners closer to the battlefield, the ways in which law is understood and practiced is changing.

Lawyers stories' departure from an imagination of law as an entity that is separate from politics marks a fundamental change. Unlike their predecessors' stories, in lawyers' most recent narratives, law is no longer based on a logic that is 
significantly different from that of politics and has no particular inclination to tame state violence. Politics, law and violence were, of course, never separate and the narration of a separation between law and politics was never 'true'. To recall Anghie's seminal contribution to this discussion, the formation of international law is rooted in colonial logic and aspirations. These origins are particularly visible in the Israeli context, being a settler-colonial project where law is understood and practiced based on ethnic divisions. Nevertheless, something has changed and the most recent era of legal stories indicates a significant difference in the ways in which the Israeli army engages with law. Indeed, if we are to posit the stories that lawyers tell as part of the social process where law is constituted, then the changed narratives do more than merely provide a truer account of a static state of affairs. The nature of legal interpretations that lawyers now offer has changed significantly, as did their interactions with military decision makers. Rather than engaging in discussions that are predicated on the assumption by which law and political considerations are often, or at least sometimes, hostile to one another, lawyers now practice law to extend violence in synergy with political desires. Lawyers' erosion of an imagination of any degree of separateness between law and politics made this state of affairs possible. 


\section{Bibliography}

Abbott, Kenneth W., et al. 2000. "The Concept of Legalization." International Organization 54(3): 401-419.

Abel, Richard L. 1995. Politics By Other Means: Law and the Struggle Against Apartheid, 1980-1994. New York: Routledge.

Alexandrowicz, Ra'anan. 2013. The Law in These Parts. Roco Films International Anghie, Antony. 2006. The evolution of international law: Colonial and postcolonial realities. Third World Quarterly 27(5): 739-753.

B'tselem. 2016. Fatalities before Operation "Cast Lead". http://www.btselem.org/statistics/fatalities/before-cast-lead/by-date-of-event (accessed October 1, 2018)

Barzilai, Gad. 1997. Between the rule of law and the laws of the ruler: The Supreme Court in Israeli legal culture. International social science journal 49(2): 193-207.

----- 2007. The Ambivalent Language of Lawyers in Israel: Liberal Politics, Economic Liberalism, Silence and Dissent. In Fighting for Political Freedom: Comparative Studies of the Legal Complex and Political Liberalism T. C. Halliday, L. Karpik and M. M. Feeley. 247-277. Oxford: Hart Publishing.

\section{----- 2012. The ambivalence of Litigation: A Criticism of Power. Jadal (13).}

Ben-Naftali, Orna. 2011. PathoLAWgical Occupation: Normalizing the Exceptional Case of the Occupied Palestinian Territory and Other Legal Pathologies. In International Humanitarian Law and International Human Rights Law: Pas de Deux. O. Ben-Naftali. 129-200. Oxford: Oxford University Press Blau, Uri and Yotam Feldman. 2009. How IDF legal experts legitimized strikes involving Gaza civilians. Haaretz, January 23. 
Blum, Gabriella. 2009. The Role of the Client: The President's Role in Government Lawyering. Boston College International \& Comparative Law Review 32: 275-287.

Burrage, Michael C. 1989. Revolution as a Starting Point for the Comparative Analysis of the French, American, and English Legal Professions. In Lawyers in Society: Comparative Theories R. L. Abel and P. Lewis. 322-374. Berkeley, Los Angeles, London: University of California Press.

Craig, Alan 2013. International Legitimacy and the Politics of Security: The Strategic Deployment of Lawyers in the Israeli Military, Lanham Maryland: Lexington Books. Cummings, Scott L. 2011. Introduction: What Good are Lawyers? The Paradox of Professionalism: Lawyers and the Possibility of Justice. S. L. Cummings. 1-31. Cambridge: Cambridge University Press.

Dezalay, Yves and Mikael Rask Madsen. 2012. The Force of Law and Lawyers: Pierre Bourdieu and the Reflexive Sociology of Law. Annual Review of Law and Social Science 8(1): 433-452.

Dickinson, Laura A. 2010. Military Lawyers on the Battlefield: An Empirical Account of International Law Compliance. American Journal of International Law 104(1): 1-28.

Dunlap, Charles J. Jr. 2001. The Revolution in Military Legal Affairs: Air Force Legal Professionals in 21st Century Conflicts. Air Force Law Review 51.

----- 2009. Lawfare: A Decisive Element of 21st-Century Conflicts?. Joint Force Quarterly (54): 34-39.

Erakat, Noura. 2017. Taking the Land without the People: The 1967 Story as Told by the Law. Journal of Palestine Studies 47(1): 18-38.

Ewick, Patricia and Susan S. Silbey. 1998. The Common Place of Law: Stories from Everyday Life, Chicago: University of Chicago Press. 
Feldman, Yotam and Uri Blau. 2009. Consent and advise. Haaretz, January 29. http://www.haaretz.com/consent-and-advise-1.269127 (accessed 1 October, 2018)

Geva, Maayan. 2016. Law, Politics and Violence in Israel/Palestine, Cham: Palgrave Macmillan

Ginosar, Shlomo. 1988. Davar, October 10.

Gordon, Neve and Nitza Berkovitch. 2007. Human Rights Discourse in Domestic Settings: How Does it Emerge?. Political Studies 55(1): 243-266.

Gordon, Neve and Nicola Perugini. 2016. The politics of human shielding: On the resignification of space and the constitution of civilians as shields in liberal wars. Environment and Planning D: Society and Space 34(1): 168-187.

Gregory, Derek. 2010. War and peace. Transactions of the Institute of British Geographers 35(2): 154-186.

Gunneflo, Markus. 2016. Targeted Killing: A Legal and Political History,

Cambridge: Cambridge University Press.

Hadar, Zvi. 1972. Illegal Command. Systems (Ma'arachot) 225.

Hajjar, Lisa. 2005. Courting Conflict: The Israeli Military Court System in the West Bank and Gaza, Oakland: University of California Press.

------ 2006. International Humanitarian Law and "Wars on Terror": A Comparative Analysis of Israeli and American Doctrines and Policies. Journal of Palestine Studies 36(1): 21-42.

Halliday, Terence C., et al. 2007. The Legal Complex in Struggles for Political Liberalism. In Fighting for Political Freedom: Comparative Studies of the Legal Complex and Political Liberalism. T. C. Halliday, L. Karpik and M. Feeley, 1-42. Oxford, Hart. 
Hasian, Marouf Jr. 2016. Israel's Military Operations in Gaza: Telegenic Lawfare and Warfare, Oxon: Routledge

IDF. 1990. IDF Spokesperson. March 3

Inbar, Zvi. 2002. The MAG Corps and the Held Territories. Law and Military: the IDF legal system's publication 16(1).

----- 2005. Scales and Sword: The basis of military law in Israel. Tel Aviv: Israel Defense Forces Publishing, MAG Corps.

Jones, Craig A. 2015. Frames of Law: Targeting Advice and Operational Law in the Israeli Military. Environment and Planning D: Society and Space 33(4): 676-696. ----- 2016a. Lawfare and the juridification of late modern war. Progress in Human Geography 40(2): 221-239.

------ 2016b. Targeted Killing, Lawfare and the Deconstruction of the Battlefield. In American Studies Encounters the Middle East. A. Lubin and M. M. Kraidy. 207-240, Chapel Hill: The University of North Carolina Press

Jones, Craig A. and Michael D. Smith. 2015. War/Law/Space: Notes toward a legal geography of war. Environment and Planning D: Society and Space 33: 581-591. Kasher, Asa. 2010. A Moral Evaluation of the Gaza War - Operation Cast Lead. http://jcpa.org/article/a-moral-evaluation-of-the-gaza-war-\%E2\%80\%93-operationcast-lead/ (accessed 1 october, 2018)

Kennedy, David. 2006. Of War and Law. Princeton: Princeton University Press. Koskenniemi, Martti. 1990. The Politics of International Law. European Journal of International Law 1: 4-32.

Kretzmer, David. 2002. The Occupation of Justice: The Supreme Court of Israel and the Occupied Territories. Albany: State University of New York Press 
Lohr, Michael F. and Steve Gallotta. 2003. Legal Support in War: The Role of Military Lawyers. Chicago Journal of International Law 4(2): 465-478.

Luban, David, J. 2013. Military Necessity and the Cultures of Military Law. Leiden Journal of International Law 26(02): 315-349.

Masri, Mazen. 2017. Colonial Imprints: Settler-Colonialism as a Fundamental Feature of Israeli Constitutional Law. International journal of law in context 13(3): 388-407 Mendelblit, Avichai. 2010. The testimony of the MAG, Avichai Mendelblit, in front of the Public Commission to Examine the Maritime Incident of 31 May 2010 (Turkel Commission), Part 2.

Mitchell, George. 2001. Sharm El-Sheikh Fact-Finding Committee Report. http://eeas.europa.eu/mepp/docs/mitchell_report_2001_en.pdf (accessed 1 october, 2018)

Nelson, Robert L. and David M. Trubek. 1992. Introduction: New Problems and New Paradigms in Studies of the Legal Profession. In Lawyers' Ideals/Lawyers' Practices: Transformations in the American Legal Profession. R. L. Nelson, D. M. Trubek and R. L. Solomon. 1-28. Ithaca and London: Cornell University Press. New York Times. 1990. Israel Declines to Study Rabin Tie to Beatings. 12 July Orr, Zvika and Daphna Golan. 2014. Human rights NGOs in Israel: collective memory and denial. The International Journal of Human Rights 18(1): 68-93. Sfard, Michael. 2004. International Litigation in Domestic Courts. The Trial (HaMishpat) 9.

Shamgar, Meir. 1967. Reaction to the finding of weapon. Internal IDF memo Sharvit Baruch, Pnina. 2009. Hamas, the Gaza war and accountability under international law. Paper presented at the Jerusalem Centre for Public Affairs, 18 June, Jerusalem, Israel. 
Sharvit-Baruch, Pnina and Noam Neuman. 2011. Warning civilians prior to attack under international law: theory and practice. Israel Yearbook on Human Rights 41: $137-195$.

Shefi, Dov. 1983. The Status of the Legal Adviser to the Armed Forces: His Functions and Powers. Military Law Review (100) 119-134

Slim, Hugo. 2003. Why Protect Civilians? Innocence, Immunity and Enmity in War. International Affairs 79(3): 481-501.

Straschnov, Amnon. 1994. Justice Under Fire. Tel Aviv: Yedioth Aharonoth Books. Talmor, Ronny. 1990. The Use of Firearms by the Security Forces in the Occupied Territories, Jerusalem: B'Tselem - The Israeli Informaiton Center for Uhman Rights in the Occupied Territories.

Viterbo, Hedi. 2016. Rights as a Divide-and-Rule Mechanism: Lessons from the Case of Palestinians in Israeli Custody. Law \& Social Inquiry 41(4).

Weisberg, Richard H. 2004. Loose Professionalism or Why Lawyers Take the Lead on Torture. In Torture: A Collection. L. Sanford. 299-306. Oxford: Oxford University Press.

Weizman, Eyal. 2010. Legislative Attack. Theory, Culture \& Society 27(6): 11-32

----- 2011. The Least of All Possible Evils: Humanitarian Violence from Arendt to Gaza. London; New York: Verso Books.

Weizman, Elian. 2015. Cause Lawyering and Resistance in Israel. Social \& Legal Studies 25(1): 43-68.

Winograd, Eliyahu. 2008. Winograd Commission Report - The commission of inquiry into the events of military engagement in Lebanon 2006.

Yahav, David and Uzi Amit-Kohn. 1993. Israel, the "Intifada" and the Rule of Law, Tel Aviv: Israel Ministry of Defense Publications. 


\section{CASES CITED:}

Taha vs. Minister of Defense. 1988. (HCJ) 591

\section{INTERVIEWS CITED:}

Officer D. 2013. Interview with Maayan Geva, 16 January

Officer E. 2012. Interview with Maayan Geva, 28 November

Shamgar, Meir. 2013. Interview with Maayan Geva, 25 February

Shiff, Ilan. 2013. Interview with Maayan Geva, 30 January

Straschnov, Amnon. 2013. Interview with Maayan Geva, 31 December

Yahav, David. 2013. Interview with Maayan Geva, 5 March 